\title{
Questões em torno do poder sagrado na lgreja: indicativos pastorais na perspectiva do protagonismo laical
}

\author{
Matters on Sacred Power in the Church: Pastoral \\ significatives for the perspective of lay protagonism
}

Roberto Nentwig

\section{Resumo}

Este artigo trata de uma questão que está ligada às resistências ao protagonismo laical: o poder sagrado na Igreja. Ao longo da história eclesial, os ministros foram revestidos de um grau de sacralidade e de poder, o que dificulta, por vezes, a inserção dos leigos e leigas. Também a concentração do poder pontifício é evidente. As sombras históricas se confrontam com a proposta Evangélica: Jesus, um leigo, ensinou aos discípulos por exemplos e por palavras que a autoridade não é o exercício do domínio hierárquico. A comunidade que surgiu depois da Páscoa, contempla, por sua vez, uma pluralidade de serviços e ministérios. Diante das questões colocadas, apresentamos algumas pistas que apontam para a descentralização do poder eclesial: complementação entre o poder institucional e o poder carismático; implementação de caminhos de sinodalidade e liberdade; criação de comunidades de tamanho humano; promoção de uma Igreja ministerial e do protagonismo laical; autoconsciência da Igreja como servidora do mundo.

Palavras-chave: Poder. Sacralidade. Igreja. Ministros. Leigos.

\section{Abstract}

This article focuses on a matter of reference as to the resistances to lay protagonism: in the reality of sacred power in the Church. As along ecclesial 
history, ministers have been given a degree of sacredness and power, that by times, makes it difficult for the real insertion of the lay community into the Church. Also, the concentration of pontifical power is apparent. Historical shadows are confronted with the Gospel proposal: Jesus, a lay man, taught his disciples - as by examples and words - that authority is not the exercising of hierarchical power. The community which arose after Easter, contemplates in its reality, a pluralism of services and ministries. As by such standing matters, we are then bound for bringing up some higher clues that direct to the decentralization of ecclesial power: complementation between the institutional and charismatic power; the implementation of sinodality and of freedom paths; the raising of communities of a human-sized ideal; the promotion of a ministerial Church and of the leading role of the lay people; the self-consciousness of a Church as server of the World.

Keywords: Power. Sacredness. Church. Ministers. Lay.

\section{Introdução}

A exortação apostólica Christifideles Laici, publicada em 31 de dezembro de 1988 por João Paulo II, completa 30 anos. Tal evento serviu de motivação para que a Igreja do Brasil fizesse de 2018 o Ano do Laicato, tendo como tema: “Cristãos leigos e leigas, sujeitos na 'Igreja em saída', a serviço do Reino" e o lema: "Sal da Terra e Luz do Mundo". ${ }^{1}$ A discussão sobre o protagonismo do laicato é recorrente, sinal de que existe muito por fazer. São inúmeros os leigos e leigas que se engajam nas atividades pastorais e são sinais do Reino no mundo, mas isso não nos tira a sensação de que ainda somos tímidos em tal engajamento. Infelizmente, a dicotomia, por vezes no âmbito da rivalidade entre leigos e clérigos, é ainda percebida na Igreja. A insistente crítica do Papa Francisco ao clericalismo é sinal de que neste âmbito existem doenças que ainda carecem de remédio.

Diante de tal panorama, trazemos neste artigo uma questão candente que está diretamente ligada às resistências que se antepõem ao protagonismo laical: o poder sagrado na Igreja. Ao longo da história eclesial, os ministros foram revestidos de um grau de sacralidade e de poder, de modo que os

\footnotetext{
${ }^{1}$ Já é bem difundido o documento lançado para motivar o ano do laicato: CNBB, Doc. 105.
} 
sacerdotes ocupam uma posição predominante no contexto pastoral, o que dificulta, por vezes, a inserção dos leigos e leigas. Aqui não se trata de uma crítica à moral aos homens ordenados. Certamente, existem muitos padres e bispos $^{2}$ comprometidos com sua missão. A questão que se coloca é estrutural, ou seja, o poder sacro dos ministros depende de uma cultura já instituída, não meramente das escolhas individuais das pessoas.

No primeiro momento, traremos brevemente algumas luzes do Novo Testamento, sobretudo dos Evangelhos, a respeito da sacralidade e do poder ministerial, voltando-nos à pessoa de Jesus Cristo. Depois, apresentaremos algumas sombras históricas neste âmbito. Por fim, traremos alguns indicativos pastorais necessários para uma mudança.

\section{Luzes neotestamentárias sobre a sacralidade e o poder}

A Sagrada Escritura nos ajuda a avaliar o processo de compreensão sobre o poder sagrado ao longo da história. Primeiramente, veremos em que medida o serviço ministerial de Jesus e da comunidade neotestamentária era considerado algo sagrado e como era distribuído o serviço eclesial. Posteriormente, veremos como Jesus entende o exercício do poder.

\subsection{Laicidade, ministerialidade e sacralidade}

Para elucidar a reflexão sobre o poder sagrado, a primeira coisa que nos parece relevante é a laicidade de Jesus: Jesus viveu com radicalidade uma vida laical, pois não se utilizou de nenhum subterfúgio que o separasse do mundo. Jesus era um leigo, não no sentido depreciativo do termo, mas sim no sentido de que não se identificava com nenhuma classe. Foi considerado um profeta, ${ }^{3}$ rabino ou mestre: no entanto, não pertencia a nenhum grupo ou casta religiosa. Vivia ele como qualquer pessoa, inserido no século, vestia-se como o seu povo, frequentava bodas e banquetes, comia e bebia com qualquer pessoa, mesmo que isso provocasse escândalo (Mt 11,6; 13,57; 26,31). ${ }^{4}$

O Novo Testamento designa Jesus como sumo sacerdote na carta aos Hebreus, mas de um modo original, não de acordo com a ideia

\footnotetext{
${ }^{2}$ Aqui não mencionaremos os diáconos casados, por estarem mais próximos da índole secular. Muito embora, também eles são revestidos, por vezes, de uma demasiada sacralidade.

${ }^{3}$ Jesus se identifica com a linha profética: Lc 7,16.39; Mt 21,11.46; Jo 4,19; 9,17.

${ }^{4}$ CASTILLO, J. M., Víctimas del pecado, p. 22-23.
} 
veterotestamentária de sacerdócio. A condição para ser sacerdote no Antigo Testamento era a separação, dignidade que dependia da pertença à família de Aarão e à estirpe de Sadoc (Ex 29, 29-30; 40,15; Eclo 45,13-16; 15-19; 24-30). A eles estavam relacionados rituais solenes, sacrifícios, unções e vestimentas especiais (Ex 29; Lv 8-9). O sacerdócio de Cristo, porém, distingue-se por ser real, não meramente ritual ( $\mathrm{Hb} 5,7-10 ; 9,11-28)$. Jesus em momento algum exigiu separação ou distinção especial, acabando os seus dias como um rejeitado entre ladrões. Deste modo, Ele consumou o seu sacerdócio. Fez de sua vida uma oferenda sacerdotal, mas jamais se identificou com a classe sacerdotal de seu tempo. Prova disso é que o termo iereús (sacerdote) não é aplicado nenhuma vez a Ele ou aos seus discípulos. ${ }^{5}$

O Novo Testamento chama os cristãos de sacerdotes (Pd 2,5. 9; Ap $1,6 ; 5,10 ; 20,6)$, mas não afirma que os ministros das comunidades eram sacerdotes, como acontecia na religião judaica. O sentido novo que se dá remete-se ao sacerdócio de Cristo, como é elaborado na Carta aos Hebreus. Jesus é sacerdote, não historicamente, mas em um sentido espiritual: participa da condição de sofrimento humana e, portanto, pode auxiliar os que sofrem ( $\mathrm{Hb}$ 2,17-18); realiza uma existência oblativa oferecendo a sua própria vida, até morrer gritando em lágrimas ( $\mathrm{Hb} 5,5-10)$ - uma existência oferecida na morte, uma só vez, por fidelidade a Deus e para o bem do ser humano $(\mathrm{Hb}$ $9,11-28){ }^{6}$

Portanto, a experiência cristã primordial não levou a Igreja primitiva a sacerdotalização de seus ministros. Cristo é o único sumo-sacerdote, ao modo espiritual, como afirmamos. Os ministros das comunidades primitivas não se pareciam com os sacerdotes judeus ou pagãos, eram acima de tudo, servidores da comunidade. Seria impossível aqui fazer um panorama completo dos ministérios presentes no Novo Testamento, não somente pela brevidade que exige este artigo, mas igualmente pela complexidade da questão. O que sabemos é que havia uma grande diversidade de pessoas que exerciam a sua ministerialidade. ${ }^{7}$ Paulo é o maior testemunho sobre este assunto. Sabemos que o apóstolo dos gentios pede consideração pelas pessoas que trabalhavam como presidentes e exortadores da comunidade (1Ts 5,12-13). Nomeia pessoas que

\footnotetext{
${ }^{5}$ CASTILLO, J. M., O novo papa, novo modelo de sacerdote.

${ }^{6}$ TABORDA, F., A Igreja e seus ministros, p. 32-42.

${ }^{7}$ Para uma abordagem completa, ALMEIDA, A. J., O ministério dos presbíteros-epíscopos na Igreja do Novo Testamento. As informações que se seguem se baseiam nesta fonte. Também: TABORDA, F., A Igreja e seus ministros, p. 75-106.
} 
exercem importantes serviços, sem precisar sua função (1Cor 16,15-16). Ao deixar as comunidades, destinava sempre delegados que ficavam responsáveis por elas (1Cor 16,$3 ; 2$ Cor 8,22-23).

São relevantes as listas de carismas, serviços e ministérios: Paulo cataloga uma série de funções eclesiais (1Cor 12,4-11; 12,28-31; 14,6; Rm 12,6-8). Destaca três grupos que parecem ter relevância: os apóstolos, os profetas e os doutores (1Cor 12,27ss.). Os apóstolos são um grupo mais amplo que os doze, responsáveis pelo anúncio do Evangelho, geralmente vão em dois e dois (At 3,2; 15,27). Os profetas, por sua vez, falam movidos pelo Espírito, são lideranças carismáticas com importante papel nas assembleias litúrgicas (1Cor 14,3-4.22). Os doutores são responsáveis pelo ensino, como faziam os rabinos no judaísmo, como é o caso de Apolo (At 18,24).

Os diáconos, presbíteros e epíscopos já aparecem no Novo Testamento, mas certamente se diferem de como são compreendidos na atualidade. Os diáconos têm uma função difícil de determinar: são auxiliares a quem se confiava funções específicas de acordo com a necessidade das comunidades (1Cor 16,3; Fl 2,19-22). Os presbíteros (=anciãos) e os epíscopos (=vigias) aparecem unidos, sendo difícil precisar sua diferença. $\mathrm{O}$ grupo presbíterosepíscopos são lideranças dos conselhos das comunidades, representam uma autoridade moral, velam pelo bom andamento das comunidades, desempenham o ministério da Palavra, sobretudo o ensino ( $\mathrm{Tt} 1,5 ; 1 \mathrm{Tm} 3,2)$. Eram escolhidos com prudência, considerando suas virtudes (1Tm 3,4-5; 5,22).

\subsection{Poder e serviço}

É bem difundida a postura de Jesus em relação ao poder: não trata ninguém como inferior ou como superior. Sua relação com as pessoas é construída de um modo livre. Com os discípulos, estabelece uma relação de discipulado que não se caracteriza pela submissão, mas nasce da exemplaridade do Mestre, que convida os seus interlocutores a seguirem os seus passos. Jesus deu autoridade (exousía) aos discípulos (Mt 10,1), mas não se trata de poder sobre as pessoas, nem de posições de privilégio. Ele concedeu uma autoridade para expulsar demônios e curar enfermos. Importante perceber que há uma diferença substancial entre poder e autoridade. Jesus, contrário a toda pretensão de se parecer com os que exerciam o poder religioso e político, adverte os seus discípulos que os chefes das nações estão na linha de um poder-autoridade, gerador de medo 
e submissão, mas esta não deveria ser a prática da comunidade fraterna convocada por Ele (Mc 10, 42-45). ${ }^{8}$

Jesus tem, portanto, uma compreensão singular sobre o exercício do poder. Ele deu o exemplo aos seus discípulos, mas não os tratou com superioridade. O superior exige a obediência dos seus servos, mas Jesus não faz tal exigência, e chama os seus discípulos de amigos (Jo 15,15). O verbo obedecer (ypakoúein) aparece no Evangelho apenas se referindo às criaturas inanimadas. Assim, devem ser obedientes à amoreira (Lc 17,6), ao vento (Mc 4,41). Também os demônios obedecem (Mc 1,27). O Espírito do Senhor é um Espírito de liberdade (2Cor 3,17), portanto um ser humano jamais obedece, se considerarmos a letra do Evangelho. Ao invés de falar de obediência, Jesus preferiu o termo seguimento. Se não aplica o verbo obedecer aos discípulos, por outro lado, o Evangelho utiliza 67 vezes o verbo seguir. Interessante observar que usualmente o termo obedire, do latim, é utilizado para motivar a atitude da escuta (obedecer, etimologicamente significa estar sob a escuta). Embora, este seja um sentido positivo, o termo em primeira mão carrega algo de negativo, pois a submissão é própria de quem se deixa escravizar, aprisionar. ${ }^{9}$

Jesus caracteriza-se pela sua liberdade e criatividade. Não se limitava a repetir o que the fora ensinado, não reproduzia sistemas implantados, mas falava por si mesmo, com autoridade (Mc 1,27). Sua autoridade não era potestade, mas o exercício de um poder carismático, ${ }^{10}$ não realizava o exercício da submissão, mas persuadia os seus interlocutores, encantando-os com suas palavras e modo de ensinar e viver. Ou seja, Jesus não dá ordens, não manda, não exerce poder como os chefes deste mundo, não tem uma ética de sujeição, mas uma ética de atração e sedução, que impele ao seguimento. Jesus contagia as pessoas com o seu modo de ser, de agir, mas sem imposições. Bem diferente era a proposta de João Batista, que queria a mudança de vida de seus interlocutores pela ameaça (Mc 3,7-10; Lc 3,7-9). Ao se distanciar da postura do Batista, Jesus marca a ruptura entre o tempo de Israel e o tempo novo. A preocupação de Jesus era dar ao povo alegria, esperança, vida. ${ }^{11}$

São muito próprias do Evangelho as advertências quanto ao uso de uma posição de destaque, como a proibição de que os discípulos aplicassem a si mesmos o título de mestre (Mt 23,8). Também criticou os líderes religiosos

\footnotetext{
${ }^{8}$ NOLAN, A., Jesus antes do Cristianismo, p. 104-105.

${ }^{9}$ CASTILlO, J. M., A ética de Cristo, p. 177-181.

${ }^{10}$ Aqui a reflexão está fundamentada em: WEBER, M., Três tipos puros de poder legítimo, p. 2-16.

${ }^{11}$ CASTILlO, J. M., A ética de Cristo, p. 18-19.
} 
que costumavam usurpar de suas posições, evidenciando-se, vivendo um autorreferencialismo destrutivo (Mc 12,38-40). Mostra-se contrário às pretensões de poder dos discípulos que desejam ocupar os primeiros lugares (Mc 10,35-45; Mt 20,20-28; Lc 22,24-27) ou quando discutiam sobre quem é o mais importante (Mc 9,33-37; Mt 18,1-5; Lc 9,46-48): “Se alguém quiser ser o primeiro, seja o último de todos e o servo de todos" (Mc 9,35). Jesus é contra o poder dominador. Por isso, convida os mais importantes que se sentem nos últimos lugares (Lc 14,8-10) e exorta que os discípulos sejam distintos por serem servidores, como aqueles que servem à mesa, como são os camareiros e serventes (Mt 23,8-11). ${ }^{12}$

Concluímos esta seção constatando que Jesus era um leigo inserido no mundo. Não se identificou com nenhum grupo religioso, sendo chamado de sacerdote no âmbito de sua existência, não no âmbito do culto. Ensinou aos discípulos por exemplo e por palavras que a autoridade não é o exercício do domínio hierárquico. A comunidade que surgiu depois da Páscoa, certamente, teve muitas divisões internas. Porém, é evidente uma pluralidade de serviços e ministérios, havendo um empenho para que não houvesse a concentração de poder ministerial.

\section{Algumas sombras históricas em torno do poder sagrado}

A única pessoa que tem a atribuição de poder é o próprio Deus, pois Ele tem o domínio sobre todas as coisas, embora oculte sua onipotência em sua kénosis. Hoje vemos a expressão Deus todo-poderoso em muitas das orações da liturgia. Trata-se de uma expressão que gera grande discussão teológica: um Deus que pode fazer tudo parece parcial diante do sofrimento; um Deus com toda a onipotência pode legitimar os poderes de uns sobre os outros, uma legitimação divina do poder secular. Assim, mais do que um Deus todo-poderoso, precisamos de um Deus todo poderoso no amor, todomisericordioso. Deste modo, não se nega os atributos divinos, sua potestade, mas se reconhece seu despojamento na história e sua pedagogia que dá preferência às relações de liberdade, pois sabe que o ser humano não precisa de poderes que o domine.

O modo como compreendemos o poder divino tem repercussões eclesiais primordiais. A pregação que valoriza um Deus poderoso acompanhou as

${ }^{12}$ CASTILlO, J. M., Jesus, p. 356-358. 
questões de poder que perseguiram a Igreja ao longo da história. Antes do Concílio Vaticano II, a Igreja era entendida como uma sociedade perfeita e auto-suficiente (societas perfecta), explicitada em linguagem jurídica e proclamada em seu poder. Nela, a multidão dos fiéis era totalmente subordinada e dependente da hierarquia, enquanto os leigos eram relegados a um plano inferior. ${ }^{13}$ São visíveis os problemas históricos aliados à demasia potestade dado à hierarquia e à carência de uma eclesiologia que atribuísse ao leigo um valor advindo da igualdade de todos diante de Deus.

Mesmo na religião de Israel, o sacerdote não era a única figura que mediava o sagrado. Havia também os profetas e os sábios. O cristianismo, ao longo dos séculos, tornou os sacerdotes os únicos mediadores entre Deus e o povo. É difícil ver nas outras religiões uma concentração do poder mediador nas mãos de um grupo tão pequeno de pessoas em relação ao número de fiéis, como acontece na Igreja Católica. Basta pensar na insuficiência de presbíteros em muitas regiões. Muitas comunidades brasileiras não têm missa dominical, por exemplo. Também seria inviável que todo o povo fiel viesse participar regularmente do Sacramento da Reconciliação, pois a média de leigos por ministro ordenado é altíssima. São questões que parecem quase insolúveis quando se pensa na pastoral, mas se trata também de uma questão sociológica importante, pois quanto mais se concentra o poder religioso, maior é a submissão por parte dos crentes. Como fazer com que os leigos sejam verdadeiros sujeitos eclesiais como se propõe no ano do laicato? ${ }^{14}$

Além da concentração ministerial, pesa-se o modo de compreensão do ministro ordenado. Se a igreja neotestamentária tratava do tema do sacerdócio de um modo espiritual, sem considerar que os seus ministros recebessem a atribuição de sacerdotes, isso mudou posteriormente. Com o passar do tempo, o ministro ordenado se tornou um homem sagrado, um personagem separado do mundo, que não faz parte do profano, que vive em uma vida totalmente diferente da vida dos demais, tem uma veste especial, realiza ritos que só lhe dizem respeito. Não é difícil perceber que este processo de mudança é marcado pela herança dos cultos pagãos, muito próximo do que já havia no Antigo Testamento. Nesta mudança de mentalidade em torno do ministro da Igreja, reforça-se a separação entre o sagrado e o profano, uma dicotomia que,

${ }^{13}$ FORTE, B., A Igreja Ícone da Trindade, p. 29-30.

${ }^{14}$ CNBB, Doc. 105, 119-135. 
mesmo diante dos avanços teológicos e das luzes do último Concílio, não é rompida tão facilmente.

Esta visão acaba se configurando como um grande desafio pastoral para a Igreja. Isso porque o mundo surgido da crise da modernidade não aceita com a mesma facilidade a imagem do homem sagrado herdada das sociedades arcaicas. Obviamente, muitas pessoas ainda esperam que o ministro seja revestido desta aura sagrada, caracterizado como uma espécie de mediador xamânico que conduz ao sagrado. Não podemos ignorar que isso faça parte do imaginário religioso desde os primórdios, além de que precisamos considerar que a fixação em um passado sem a devida atualização é algo presente como uma tentativa de resistir ao avanço dos tempos. Mas, é oportuna a pergunta: não estaria aqui uma sombra? Não seria necessário romper com esta aura sagrada do sacerdote para que a fidelidade evangélica seja satisfeita? Parece que tal mudança é um caminho de fidelidade frutífera e de diálogo com a cultura. Por outro lado, é verdade que os ministros que tentam quebrar com este imaginário produzido são vistos com suspeita. Parece que não há escapatória: ou o ministro se vincula ao imaginário arcaico, mesmo com o risco de trair o Evangelho e de se distanciar da realidade, ou se laiciza, mesmo com o risco de ser visto com suspeita pelos membros da hierarquia e por muitos leigos do seio da própria Igreja. ${ }^{15}$

A questão não é fácil. Percebe-se na prática que, desde o seminário, o futuro presbítero é identificado com esta imagem de homem consagrado, e isso acaba sendo um alimento de sua própria perseverança ao longo dos anos de formação. O jovem seminarista espera um dia receber a ordenação, ser um homem distinto, um homem consagrado, um sacerdote. Ao ser revestido com suas vestes sacerdotais, sente-se como uma pessoa que está doando sua vida em sacrifício, é verdade, mas também se sente alguém especial, distinto, reverenciado. Certamente, não iremos aqui retirar a importância do ministério da ordem, a solução não é desqualificar a unção recebida, a força deste ministério, sua importância para a Igreja. A questão que se põe é se não transformamos a vocação em uma escolha divina que privilegia ao invés de se dar a devida atenção ao serviço que demanda do múnus sacramental. Muitos cristãos leem os textos que tratam da escolha dos discípulos como um prenúncio do ministério ordenado. Mas, é preciso que se ressalte que o convite ao discipulado se estende a todos. Aquele que abraça o ministério ordenado é

${ }^{15}$ CASTILLO, J. M., ¿Hacía dónde va el clero?, p. 16-17. 
antes de tudo discípulo e, a partir do seu discipulado, vive como um servidor da comunidade e do mundo, sem que para isso usufrua de privilégios obtidos a partir da imagem a ele atribuída - um ser separado e especial. Nesta linha, o ministro ordenado deve ter consciência de que mesmo que comumente seja designado como sacerdote, ele não está referenciado ao sacerdócio cultural do Antigo Testamento, pois o sacerdócio de Cristo levou a cabo todos os sacerdócios da história, depois da Páscoa do Senhor, qualquer ministro apenas poderá ser uma representação sacramental do seu sacerdócio. ${ }^{16}$

Existe, evidentemente, uma consagração que se vincula ao serviço evangelizador, sendo Cristo o primeiro consagrado (Jo 10,36). Cristo também consagra e envia discípulos ao mundo (Jo 17,17-19), porém, não para se tornarem pessoas distintas do mundo, mas servidores do Evangelho. Não os torna santos de antemão, mas pessoas convidadas a prolongar a sua ação no mundo pelo múnus sacerdotal, profético e régio. Nesta linha, em Cristo não há separação entre o ontológico e o funcional, e sim uma unidade. O que Cristo é e o que ele faz estão em profunda unidade: o que ele diz e faz são manifestações da profundidade do seu ser. Por isso, não podemos entender Jesus dentro de um rito religioso, mas sim uma existência sacerdotal, ou seja, uma vida que é toda dom. ${ }^{17}$ Hoje, parece necessário este resgate cristológico para entender o ministério ordenado: não se trata de realizar um rito sacerdotal, mas ter uma vida toda sacerdotal. Mas tal existência não se realiza somente dentro do templo, mas em qualquer realidade. Aliás, todo cristão vive assim, cada um em seu estado de vida ou missão: uma existência sacerdotal, pois todos os cristãos participam do sacerdócio comum pelo Batismo. ${ }^{18}$

A sacralização que se instaurou ao longo da história acontece quando a religião é entendida como uma alienação da fé, uma ilusão, quando existe a sacralização das coisas (uma espécie de mágica, o fascínio pelo rito) tornando Deus um objeto. Neste caso, a religião é fuga do mundo, não a inserção nele, o culto é um contato com o sagrado, não um diálogo com Deus, a esfera do

\footnotetext{
${ }^{16}$ GRESHAKE, G., Ser sacerdote hoy, p. 90. O Concílio Vaticano II deixa claro que os presbíteros agem in persona Christi Capitis (PO 2-3). O Concílio usa os dois termos: sacerdote e presbitero, no entanto, prefere o último, já que utiliza 125 vezes, enquanto sacerdote aparece 32. A Presbyterorum Ordinis não deixa de lado a categoria sacerdotal e tampouco a exclui, mas busca compreendê-la à luz da riqueza ministerial apresentada no Novo Testamento e no quadro do ministério da Igreja e seus ministros (SESBOÜÉ, B., Não tenham medo!, p. 87).

${ }^{17}$ CASTILLO, J. M., ¿Hacía dónde va el clero?, p. 18-19; SESBOÜÉ, B., Não tenham medo!, p. $80-81$.

${ }^{18}$ CNBB, Doc. 105, 110-111.
} 
sagrado torna-se uma fuga do profano e o sacerdote alguém alheio à vida comum. É preciso que a Igreja se abra cada vez mais a um mundo que se reconhece como profano desde a modernidade. Se compreendemos isso, devemos também compreender que o serviço da Igreja (dos leigos e dos clérigos) não tem a necessidade de um envolvimento sacral como nos tempos antigos. A liturgia continua tendo sua função especialíssima, obviamente, mas o Cristianismo não realiza um culto que está alheio ao mundo, mas sim, a atualização do mistério pascal de Cristo que impele os discípulos e discípulas a viver no mundo configurado a Cristo, como sinais atuantes do Reino de Deus. É importante frisar que uma dessacralização do ministério ordenado é uma horizontalização irresponsável, uma negação da própria fé. Não estamos aqui defendendo esta proposição, mas sim indicando que a demasiada sacralização do ministro ordenado, a ênfase dada ao aspecto ontológico em detrimento da funcionalidade, a separação do mundo, cria dificuldades para que a Igreja cumpra sua missão na sociedade. ${ }^{19}$

Por fim, ao se tratar das sombras que rondam o poder eclesial, cabe a menção do poder pontifício. A Igreja Católica tem suas bases governamentais na monarquia medieval, atribuindo poderes ilimitados ao Bispo de Roma. Voltando os olhos para o Código de Direito Canônico, percebemos que o papa tem um poder supremo, pleno, imediato e universal, ${ }^{20}$ contra o qual não há apelação, nem recurso. ${ }^{21}$ Além disso, o Pontífice não é julgado por ninguém, ${ }^{22}$ não precisa prestar contas de suas decisões e tem o direito de ser juiz sobre qualquer decisão que se tome em assuntos espirituais ou afins. ${ }^{23}$ Também o Concílio Vaticano II afirma que "o Romano Pontífice, em virtude do seu cargo de vigário de Cristo e pastor de toda a Igreja, tem nela pleno, supremo e universal poder, que pode sempre exercer livremente". ${ }^{24}$

$\mathrm{Na}$ base do poder papal está a interpretação do Evangelho de Mateus (Mt 16,19), que versa sobre as palavras ditas a Pedro, consideradas ao longo da história a fundação da Igreja sobre a pedra fundamental (o primeiro papa) e seus sucessores. Congar, grande estudioso autorizado sobre as questões eclesiológicas, ao lamentar os abusos cometidos por Pio XII, afirma que os

\footnotetext{
${ }^{19}$ CASTILLO, J. M., ¿Hacía dónde va el clero?, p. 24-30.

${ }^{20}$ CIC Cân. 331.

${ }^{21}$ CIC Cân. 333.

${ }^{22}$ CIC Cân. 1404.

${ }^{23}$ CIC Cân. 1401; 1404.

${ }^{24}$ LG 22. Também CASTILLO, J. M., O problema da autoridade na Igreja Católica.
} 
padres da Igreja interpretavam as palavras de Jesus ditas a Pedro (Mt 16,19) como fundação da Igreja e não a instituição da igreja romana com absolutização do poder papal. O grande erro, de acordo com o autor, é defender a autoridade divina aliada ao poder de jurisdição, ou seja, elevar à categoria teológica uma questão que é de âmbito jurídico. ${ }^{25} \mathrm{~A}$ origem divina é o grande argumento para legitimar o poder papal absoluto, bem como, em grau inferior, o poder da hierarquia da Igreja: magistério e bispos. No entanto, mesmo os avanços recentes do Concílio e dos últimos pontificados não foram suficientes para dar os passos necessários em busca da superação dos problemas relacionados ao poder na Igreja.

Certamente, temos que reconhecer que o papa Francisco exerce seu ministério a partir de uma compreensão afinada com o Evangelho, mas estruturalmente ainda o quadro é o mesmo. Os gestos e palavras do Bispo de Roma, como ele mesmo prefere ser chamado, são sementes de mudança: acreditamos que o Espírito guia a Igreja para o despojamento do poder.

\section{Pistas para a renovação eclesial relacionadas ao poder sagrado}

Diante das questões que se colocam, sem pretensões de exaustividade, apresentamos algumas pistas que apontam para a descentralização do poder eclesial. Grande parte delas já são bem trabalhadas por pastoralistas dentro de uma eclesiologia afinada com o Concílio Vaticano II, mas cabe ressaltar algumas delas diante de certos imobilismos que ainda se constatam na Igreja. Destacamos que a descentralização de poder está diretamente ligada ao incremento do protagonismo laical e, portanto, este elemento está aqui como pano de fundo. ${ }^{26}$

\subsection{Complementação entre o poder institucional e o poder carismático}

Os cristãos primitivos se entendem a partir do princípio pneumatológico: Jesus deixou o seu Espírito vivificante e, portanto, os cristãos são por ele possuídos. Pelo Batismo, tornam-se pneumáticos. O livro dos Atos dos Apóstolos aplica a profecia de Joel a toda comunidade cristã: todos recebem o Espírito, formando uma comunidade profética. A experiência de

\footnotetext{
${ }^{25}$ CASTILLO, J. M., O problema da autoridade na Igreja Católica.

${ }^{26}$ Indicativos e encaminhamentos de ações pastorais, neste sentido, foram apontados pelo Documento da CNBB referente ao ano do laicato: CNBB, Doc. 105, 274.
} 
conotação carismática era muito presente na Igreja, ocupando toda a costa do mediterrâneo. Lá havia muitos pneumáticos que viviam a partir de uma experiência pascal e pentecostal, a partir do Batismo no Espírito, seguindo uma escatologia já realizada: já se sentiam vivendo na plenitude do tempo. A ação pastoral e ministerial da Igreja nascente viveu em muito a partir deste horizonte: sem excluir a ação da autoridade eclesial, era uma comunidade de "apóstolos e profetas" (Ef 2,20), uma comunidade que primava pelo fim das discriminações e exclusões (Gl 3,26-28), uma comunidade livre, de pessoas livres, onde prevaleciam as relações recíprocas, igualitárias, onde não havia o predomínio do poder-dominação. ${ }^{27}$

As exigências dos tempos pedem uma retomada pneumatológica, em consonância com o Concílio Vaticano II, que afirma que o Espírito é como alma do Corpo que é a Igreja. ${ }^{28} \mathrm{O}$ Espírito move, impulsiona, é vida, é fogo, é vento: "O vento sopra onde quer e ouves a sua voz, mas não sabes de onde vem, nem para onde vai. Assim é também todo aquele que nasceu do Espírito" (Jo 3,8). Sem a valorização da ação do Espírito, a Igreja pode cair no enrijecimento de suas estruturas históricas. A mudança de época em que vivemos nos coloca diante de uma crise das instituições, o que propicia a consideração da essência carismática da Igreja, bem como desconsiderar o que já está pronto e o que está determinado. Vivemos no tempo da mudança, da decisão, do discernimento, ações típicas do Espírito Santo. Certamente, uma Igreja do Espírito não se opõe à Igreja institucional, mas impregna todas as suas partes e estruturas com a força de Deus, com sua suavidade e imprevisibilidade, sem o peso da imposição, do rigorismo, da intransigência.

Neste tempo aberto ao Espírito, as instituições se encontram em declínio, perdem sua força, sendo até mesmo substituídas pela relação pessoal. O que importa ao mundo pós-moderno é a comunicação emocional, ou seja, aquela que firma as relações nas recompensas que derivam dela. ${ }^{29}$ Segundo Weber, a dominação carismática não se baseia no poder constituído, ou seja, em uma carreira, diferenciando-se da dominação imposta: a liderança se impõe pela capacidade de influenciar os outros. ${ }^{30}$ Aqui está a base do conceito moderno de liderança que pode valer muito para a Igreja hodierna: a Igreja deveria se valer mais do carisma, da força do testemunho e do Espírito que impele os fiéis

\footnotetext{
${ }^{27}$ SCHILLEBEECKX, E., Por uma Igreja mais humana, p. 50-56.

${ }^{28}$ LG 7.

${ }^{29}$ GIDDENS, A., Un mundo desbocado, p. 74.

${ }^{30}$ WEBER, M., Economia e sociedade, p. 323-355.
} 
ao discipulado do que o apelo à obediência e a sua constituição hierárquica. A autoridade na Igreja não é de natureza jurídica ou política, a verdadeira autoridade é a autoridade evangélica.

O que o mundo ávido pela leveza do Espírito e desconfiado da rigidez institucional espera da Igreja? Deverá ser, segundo Moltmann, uma comunidade em êxodo que tenha atenção à pessoa (a personalização é palavra chave da ação pastoral), que realize um culto de proximidade e subjetividade (é preciso derrubar os muros de separação, construir pontes de comunhão), que cultive as relações interpessoais e alimente a esperança no Reino (acreditar em um futuro melhor, lutando contra os "desumanismos"). ${ }^{31}$ Uma Igreja do Espírito trará leveza à instituição, não permitindo que o desejo de autoconservação leve-a a surdez diante dos anseios do mundo e que a autoridade de seus ministros seja confundida com poder-dominação.

\subsection{Implementação de caminhos de sinodalidade e liberdade}

A Igreja é, antes de tudo, um povo de batizados, o Corpo de Cristo, corpo sacramental enquanto alimentada pela Eucaristia. A Igreja-Povo de Deus é, sobretudo, uma comunidade de fiéis, que se visualiza de diversos modos: comunidade local, comunidade diocesana, família ou Igreja doméstica, comunidade paroquial, comunidade presbiteral, comunidade religiosa, comunidade universal... ${ }^{32}$ Não se trata de entender a Igreja a partir de um critério meramente sociológico ou numérico. A Igreja é um mistério de comunhão, um povo congregado na Trindade. São João Crisóstomo afirma que "Sínodo é o nome da Igreja". Esta definição é um resumo da eclesiologia do Vaticano II. O termo sínodo denota um caminho feito em conjunto, significando que a Igreja é um povo peregrino, um povo que caminha em conjunto, tendo o Reino como meta definitiva - a grande comunhão fraterna escatológica. ${ }^{33}$

A eclesiologia sinodal, de comunhão, é um chamado para a conversão pastoral da Igreja-instituição. Tal eclesiologia exige uma Igreja livre, pois não existe comunhão sinodal sem liberdade: se a Igreja é povo, é também povo livre. Na história recente, percebemos que a constituição dos estados democráticos (dos povos) se realizou a partir da luta pela liberdade e contra a absolutização do poder. Interessante observar que a luta emancipatória dos

\footnotetext{
${ }^{31}$ MOLTMAN, J., Teologia de la esperanza, p. 393-436.

${ }^{32}$ CODINA, V., Eclesiologia do Vaticano II, p. 466-467.

${ }^{33}$ CODINA, V., Eclesiologia do Vaticano II, p. 468.
} 
últimos séculos se realizou na contramão da hierarquia eclesiástica. Esqueceu a hierarquia da Igreja que Jesus é o homem livre que proclamou a liberdade a todo custo? A Igreja segue, não apenas como a última monarquia absoluta do Ocidente, mas igualmente tem dificuldades de gerir processos democráticos em seu seio. No século XX, mesmo depois do Concílio Vaticano II, tivemos o "inflacionamento" do Magistério, que escreveu sobre uma vastidão de temas, rejeitando incisivamente os modos de pensar que se distanciavam dos textos oficiais. Ser católico ainda parece ser sinal de uma pessoa obediente, que segue o que é declarado pelos pastores. Como fazer um povo ainda acostumado com o controle da hierarquia eclesiástica ser um povo emancipado, livre e participante nas decisões da Igreja ${ }^{34}$

A Igreja encontra-se desafiada a realizar um caminho de sinodalidade e liberdade. Trata-se de uma agenda pendente. Segundo Codina, entre as tarefas que aguardam o Bispo de Roma, em consonância com a aclamação popular, estão: a descentralização eclesial, a participação do povo na escolha dos bispos e no modo de escolher o Papa, a valoração dos sínodos episcopais como deliberativos e não meramente consultivos, a reforma na cúria romana. ${ }^{35}$

Um governo sinodal, com a participação dos leigos, já foi a prática da Igreja no primeiro milênio. É preciso dar mais liberdade e força às conferências episcopais, além de aprimorar as relações entre o primado petrino e a colegialidade episcopal. Para tanto, as relações entre a Santa Sé, a Cúria Romana e as conferências episcopais devem ser pautadas na confiança. ${ }^{36}$ Democracia e hierarquia não são termos incongruentes, de modo que a Igreja pode avançar democraticamente sem deixar de lado a importância de seu governo. No Novo Testamento e nos primeiros séculos existem relatos sobre a escolha dos ministros por parte da comunidade, mesmo a escolha de bispos, por outro lado, hoje a escolha dos párocos compete aos bispos titulares e dos bispos às nunciaturas, ainda que se considerem as devidas consultas. ${ }^{37}$

Muitos problemas da Igreja estão ligados ao excesso do poder da Cúria romana, bem como do poder que acabam sendo atribuídos aos núncios apostólicos, nem sempre com a devida legitimidade canônica. As Igrejas locais poderiam ter autonomia nas questões da catequese, da liturgia, na dispensa dos sacerdotes e religiosos, nas nomeações episcopais, nas questões que estão

\footnotetext{
${ }^{34}$ COMBLIN, J., O povo de Deus, p. 219-226.

${ }^{35}$ CODINA, V., Para onde vai a Igreja?

${ }^{36}$ BARROS, P. C., Colegialidade Episcopal no Vaticano II, p. 199-224.

${ }^{37}$ GONZÁLES FAUS, J. I., Nenhum Bispo Imposto, p. 143ss.
} 
ligados a sua região. Isso deveria ser feito com autonomia, sem que o Bispo de Roma tivesse que tutelar tudo. ${ }^{38}$ Neste sentido, o papa não deve aparecer sempre como um bispo acima dos outros bispos. O que se deseja é uma verdadeira comunhão, sem que seja um mero nivelamento irracional; uma ação que nasce do mistério trinitário, gerando uma Igreja de carismas e ministérios, de localidade e universalidade, de unidade e pluralidade, de instituição, mas acima de tudo do Espírito. ${ }^{39}$ Francisco dá um grande passo neste sentido ao apontar que o papa deve assumir sua posição fundamentalmente como Bispo de Roma. Suas atitudes de abertura parecem abrir terreno para uma Igreja sinodal e para a implementação de ações democráticas e livres. Estamos diante de sementes lançadas.

A sinodalidade poderia inspirar ações em todos os âmbitos. Hoje vemos que as comunidades enfrentam grandes dificuldades com a nomeação de alguns ministros ordenados sem sintonia com a comunidade paroquial. Em muitas ocasiões, o pároco toma as decisões sem consultar a comunidade. A valorização dos conselhos e o planejamento participativo são aspectos pastorais imprescindíveis para a administração do poder eclesial. Estaria aqui ótimo caminho para o engajamento laical em uma Igreja mais sinodal e livre.

\subsection{Criação de comunidades de tamanho humano}

Nos primeiros séculos, o lugar de reuniões das comunidades cristãs era a casa-moradia e seu núcleo era a casa-família. As igrejas domésticas fundadas por Paulo eram pequenas comunidades, compostas de algumas dezenas de pessoas e eram comunidades domésticas. ${ }^{40}$ Por isso, o Novo Testamento não fala apenas da Igreja em seu sentido universal, bem como de igrejas (ekklesíai): são comunidades existentes em uma localidade. Importante aqui entender que a Igreja universal não se define como um agrupamento de pequenas igrejas, pois a pequena igreja não é uma mera parte, na pequena unidade já está o todo. ${ }^{41}$

Este modelo de comunidades domésticas do Novo Testamento é inspirador para os tempos atuais, pois a globalização impõe um horizonte de individualismo: existe a necessidade de espaços que propiciem a personalização

\footnotetext{
${ }^{38}$ COMBLIN, J., O povo de Deus, p. 375.

${ }^{39}$ ALMEIDA, A. J., Igrejas locais e colegialidade episcopal, p. 98-99.

${ }^{40}$ CODINA, V., Para compreender a Eclesiologia a partir da América Latina, p. 72.

${ }^{41}$ ALMEIDA, A. J., Igrejas locais e colegialidade episcopal, p. 13-18.
} 
e o cultivo da vida de fé, ${ }^{42}$ pois as estruturas e as grandes massas colocam grandes limites à vida pastoral.

O mais importante é que as comunidades tenham tamanho humano: ${ }^{43}$ devem ser comunidades pequenas, afetivas e acolhedoras, concretizadas em espaços de resgate da identidade, da dignidade e de autoestima, aberta a todos. Na comunidade de tamanho humano as pessoas se conhecem pelo nome, são humanizadas e integradas, não apenas recebem uma assistência religiosa no sentido estrito do termo. É preciso um empenho de superação do modelo Igreja-sociedade, no qual o fiel é um anônimo que recebe os sacramentos básicos para manter um verniz de vida cristã. ${ }^{44}$ É preciso superar a Igreja como uma realidade meramente espiritual que não permite o encontro de corpos que coabitam, tocam-se, partilham sentimentos, valores, ideias... ${ }^{45}$ Para ser comunidade não basta um aglomerado de pessoas. É preciso repensar o conceito de comunidade, fazendo da mesma um local de emancipação de indivíduos, que tenham suas decisões expressas diante das instituições, criando espaços de autonomia e de acolhida das diferenças. As comunidades de dimensão humana contribuem para que os seus integrantes sejam protagonistas da evangelização. ${ }^{46}$

Nas pequenas comunidades não existem grandes massas impessoais. $\mathrm{O}$ elemento fundamental de uma comunidade deve ser o grau de pertença de seus indivíduos. Nesta linha, as comunidades de tamanho humano são fortemente indicadas para a renovação das posturas eclesiais diante do desafio da pastoral urbana, configurando a paróquia como uma rede de comunidades. ${ }^{47}$ Certamente, nestas pequenas comunidades, o protagonismo do laicato e descentralização do poder é mais efetivo do que nas grandes estruturas.

\subsection{Promoção de uma Igreja ministerial e do protagonismo laical}

O Concílio Vaticano II mudou a concepção sobre o sacerdote. No âmbito da liturgia temos um exemplo emblemático, ao propor que não tenhamos um sacerdote celebrante, mas sim uma comunidade toda

\footnotetext{
${ }^{42}$ EG 77.

${ }^{43}$ BRIGHENTI, A., Igreja comunidade e Igreja local, p. 157.

${ }^{44}$ BOFF, L., E a Igreja se fez povo, p. 82.

${ }^{45}$ COMBLIN, J., O povo de Deus, p. 149-150.

${ }^{46}$ BRIGHENTI, A., Igreja comunidade e Igreja local, p. 156-157.

${ }^{47}$ CNBB, Doc.100, 244-256.
} 
sacerdotal. Como ouvimos repetidas vezes, não é o padre que celebra, mas toda a comunidade é celebrante, por isso, está ao redor do altar, presidida por um ministro ordenado. Não raras vezes um ministro leigo preside a celebração dominical. ${ }^{48}$

Seguindo a linha conciliar, resgata-se a mentalidade de uma Igreja comunhão que, por sua vez, valoriza mais a unidade dos fiéis do que a distinção entre clérigos e leigos. ${ }^{49}$ Nesta perspectiva, reconhece-se a ação pneumática no interior da vida eclesial e se redescobre o sacerdócio universal do Povo de Deus: qualquer batizado, independente de seu carisma específico, é um homo christianus, ou seja, aquele que é incorporado ao mistério de Cristo.

Por consequência, toda a Igreja é carismática e ministerial nas suas diferentes formas de serviço pessoal e comunitário (movimentos, associações, etc.). Um novo binômio se instaura, mais adequado que o clérigo-leigos, ou seja, o binômio comunidade-ministérios: no interior da comunidade batismal surge uma diversidade de serviços e ministérios que se complementam para edificação do corpo eclesial, sem que haja relações de superioridade de uns em relação a outros. ${ }^{50}$

$\mathrm{Na}$ prática, porém, existe uma concentração de atribuições sobre o ministro ordenado da Igreja. É impossível que um único indivíduo tenha todos os carismas para desempenhar todas as funções que dele se exige. Em geral, existe alguém que prega bem, outro que atende e aconselha, outro ainda que é um bom administrador. Como esperar que um único homem, além de todas as exigências morais que se impõe diante dos olhares dos fiéis, consiga dar conta de todas as tarefas e de um modo eficaz? O que acontece é que, no âmbito católico, valorizamos muito a ontologia do ministro (o caráter indelével da ordem) de tal modo que a funcionalidade (como o ministério dá conta de suas funções) ficou em segundo lugar. A tradição protestante, por outro lado, considerou a funcionalidade do ministério, porém desqualificou o aspecto ontológico: o mais importante é ter um ministro que atenda àquela demanda específica do serviço eclesial, mesmo que este não seja um ministro devidamente ordenado: pregar, aconselhar, administrar a comunidade eclesial são tarefas, por vezes, distribuídas entre várias pessoas, o que ameniza o peso das tarefas e responsabilidade, possibilitando que exista maior concordância entre o carisma e o serviço. Parece que é preciso equilibrar a balança, sem

\footnotetext{
${ }^{48}$ BRIGHENTI, A., Do sacerdote celebrante a uma assembleia sacerdotal.

${ }^{49}$ LG 10.

${ }^{50}$ FORTE, B., A Igreja Ícone da Trindade, p. 31.35.
} 
deixar a riqueza do valor ontológico da ordem, um valor positivamente mantido com maior vigor pela tradição católica. ${ }^{51}$

Os ministros ordenados não conseguem dar conta da demanda pastoral que se exige deles. Um exemplo clássico sobre a falta de presbíteros diz respeito à grande quantidade de comunidades que não têm Eucaristia dominical. No Brasil, estima-se que o número chegue a $70 \mathrm{mil}^{52} \mathrm{~A}$ alteração deste quadro necessita de uma mudança estrutural no modo de pensar o ministério ordenado, como o faz Fritz Lobinger ao propor uma sugestão audaciosa. O autor, que foi bispo na África do Sul, visualiza uma Igreja com dois tipos de presbiteros: ministros ordenados locais e padres. Os padres corresponderiam aos presbiteros diocesanos atuais, atenderiam uma vasta área pastoral (uma grande paróquia ou um conjunto de paróquias) e teriam dedicação exclusiva, sendo celibatários. Os ministros ordenados corresponderiam aos atuais animadores de comunidades. Seriam homens capazes de conduzir as pequenas comunidades locais, viveriam nelas com suas famílias, porém receberiam a ordenação, diferentemente da prática atual. É preciso ter claro que esta discussão não pretende ser uma luta contrária ao celibato, entendido como um dom divino e uma graça para a Igreja, mas sim um modo de pensar novas formas de organizar a ministerialidade da Igreja. ${ }^{53}$

A prática ministerial do Novo Testamento deixa evidente que o critério fundamental era a comunidade: a comunidade vinha antes do ministério, de modo que o ministério está a serviço da comunidade, jamais o contrário. ${ }^{54}$ Seria de se perguntar se o direito que as comunidades têm à Eucaristia pode, de forma legítima, ser menos importante do que as tradições que fazem a Igreja definir a vida do presbítero do modo como o faz. O direito das comunidades à Eucaristia seria menos importante do que o direito dos ministros ao celibato? Tais questões parecem pertinentes.

$\mathrm{Na}$ prática, ainda o clérigo é um personagem cada vez mais raro e sobrecarregado, e o leigo por vezes assume responsabilidades sem o devido preparo ou sem o devido reconhecimento por parte da comunidade. Destacase também o crescimento do diaconato permanente, mas não raras vezes,

\footnotetext{
${ }^{51}$ BOROBIO, D. (Org.)., A celebração da Igreja, p. 402-406.

${ }^{52}$ ALMEIDA, A. J., Presbíteros Comunitários para Comunidades sem Eucaristia.

${ }^{53}$ LOBINGER, F., Padres para amanhã uma proposta para comunidades sem Eucaristia. São Paulo: Paulus, 2007. Uma atenção especial à introdução à edição brasileira, de ALMEIDA, A. J., p. 9-72. Na mesma linha, a obra: LOBINGER, F; ALMEIDA, A. J. Equipes de ministros ordenados: uma solução para eucaristia nas comunidades. São Paulo: Paulus, 2009.

${ }^{54}$ SCHILLEBEECKX, E., Por uma Igreja mais humana, p. 350.
} 
o diácono acaba sendo um suplente do presbítero na paróquia ao invés de exercer seu ministério mais próximo das realidades seculares. ${ }^{55}$ É verdade que existe um engajamento crescente do laicato e uma compreensão do seu papel na Igreja. Também se evidencia mais a participação dos leigos nas tomadas de decisões, uma progressiva democratização. No entanto, também existem recuos, os desafios continuam postos. ${ }^{56}$

\subsection{Autoconsciência da Igreja como servidora do mundo}

No âmbito das paróquias, constatamos uma distância entre Igreja e mundo. Uma estimativa otimista apostaria que em algumas cidades, onde o catolicismo é mais enraizado, consiga-se atingir 10\% da população. Comblin, neste sentido, desenha um quadro pessimista: "cada paróquia é uma ilha e tem o seu conjunto de obras. Assim não se forma o povo. A Igreja não assume a realidade da cidade, nem se projeta na cidade. A tendência crescente é isolar-se em paróquias". ${ }^{57}$ Diante do quadro de presbíteros sobrecarregados e um laicato ainda insuficiente, percebe-se que cada paróquia se fixa em si mesma, conservando suas raízes feudais. $\mathrm{O}$ que não está na paróquia parece não ter importância como ação evangelizadora. Tal situação se distancia do conceito de Igreja povo de Deus, tão bem colocado pelo Concílio Vaticano II. Diante dos resquícios da mentalidade feudal de cristandade, o que acontece é que "não somos mais um povo, somos uma paróquia". ${ }^{58}$

A abertura da Igreja ao mundo necessita de leigos que compreendam qual é a sua verdadeira missão. Segundo Paulo VI, a primeira tarefa do laicato não é o trabalho intraeclesial: "a sua primeira e imediata tarefa não é a instituição e o desenvolvimento da comunidade eclesial, esse é o papel específico dos Pastores, mas sim, o pôr em prática todas as possibilidades cristãs e evangélicas escondidas, mas já presentes e operantes, nas coisas do mundo". ${ }^{59} \mathrm{O}$ que se percebe, hoje, são muitos ministérios e serviços que fazem do leigo um mero agente da igreja para a própria igreja.

\footnotetext{
${ }^{55}$ Os diáconos permanentes podem assumir diaconias - estruturas da diocese que auxiliam na pastoral das pequenas comunidades e na evangelização dos novos areópagos e fronteiras geográficas e culturais: CNBB, Doc. 96, 103-109.

${ }^{56}$ CNBB, Doc. 105, 38-50.

${ }^{57}$ COMBLIN, J., O povo de Deus, p. 152.

${ }^{58}$ COMBLIN, J., O povo de Deus, p. 156.

${ }^{59} \mathrm{EN} 20$.
} 
É urgente a tarefa da Igreja reconhecer que sua ação não procura absorver o mundo para dentro dos domínios eclesiais, mas deve ser sinal do Reino no mundo. Deste modo, cada comunidade se torna um centro de irradiação da vida em Cristo. ${ }^{60}$ Isso pode acontecer em vários âmbitos como nos propõe o Documento de Aparecida: no mundo da cultura, na comunicação social, nos centros de decisão, na vida pública, no mundo do turismo, do entretenimento, dos clubes, esportes, cinema e centros comerciais, bem como no diálogo entre a fé e a ciência ${ }^{61}$ Uma Igreja aberta ao mundo não se limita a implementar os ministérios intraeclesiais (catequistas, ministros extraordinários da Comunhão...), mas também os ministérios em prol da sociedade (na área da comunicação social, dos direitos humanos, servidores públicos, ministérios eclesiais no mundo da política....). ${ }^{62}$

Uma Igreja que irradia a Boa Nova ao mundo não supõe ser constituída por um grupo de perfeitos, separados do resto da sociedade. São pessoas que se inserem no mundo e irradiam o Evangelho em volta de si: a pessoa vive a sua fé e com isso a irradia. Isso é herança da sinagoga, o que levou aos apologetas a falarem de uma pastoral para dentro da Igreja e de profetismo para fora. No modelo da cristandade, todos deveriam estar incluídos na Igreja instituição. ${ }^{63}$ Percebemos que no mundo cibernético as vozes dos grupos e agremiações são cada vez mais manifestas. Não raras vezes, em nome de Cristo, pessoas realizam guerras ideológicas e até religiosas. A agressividade ideológica que se evidencia nos últimos tempos leva-nos a discernir que é necessário propagar mais os valores da tolerância, do respeito e da liberdade. Cabe aos cristãos perceberem o que é, de fato, anunciar o Evangelho.

"O Evangelho não está amarrado a um tipo clássico e consagrado de articulação, herdada de um passado institucionalmente glorioso. Ele pode, novamente, ser vivido como movimento e criar para si as estruturas mais adequadas para o nosso tempo, sem polêmicas com a velha Igreja, sem lamúrias e sem espírito farisaico de quem se julga possuidor de um cristianismo mais vivo e genuíno. Uma Igreja assim compreende que não existe para si; sua função é ser sinal de Cristo para o mundo e espaço de atuação explícita do Espírito. O sinal existe para os outros. Ela é de Cristo para o mundo". ${ }^{64}$

\footnotetext{
${ }^{60}$ DA 362.

${ }^{61}$ DA 479-480; 484-508.

${ }^{62}$ CODINA, V., A missão como renovação eclesial, p. 243.

${ }^{63}$ LEUSBAUPIN, I. (Org.)., Igreja, p. 42.

${ }^{64}$ BOFF, L., Igreja, carisma e poder, p. 106.
} 
Por isso, importa à Igreja a atitude de humildade, distanciando-se de qualquer postura impositiva. Cabe a ela reconhecer os seus erros, como fizeram os últimos papas, além de viver da consciência de sua perda numérica, o que tira qualquer pretensão de sonhar um mundo católico. A Igreja, como humilde servidora do mundo, precisa estar aberta para o diálogo. Ela foi contrária à modernidade, pronunciando syllabos de condenação. Cabe destacar que os grandes avanços da humanidade, depois do renascimento, foram realizados à margem ou contrários à Igreja. Porém, grande parte destes progressos têm raízes cristãs: o avanço democrático, científico, a liberdade de expressão, o pluralismo político, a tolerância religiosa, entre outros. ${ }^{65}$ Uma Igreja servidora do mundo deverá ter atitude de diálogo respeitoso, com abertura de mente.

\section{Conclusão}

Estamos num momento de mudanças importantes em relação ao poder eclesial. De um lado, tal mudança acontece diante das circunstâncias do atual momento da história do cristianismo. A diminuição do número dos fiéis é sentida. Percebe-se que a Igreja segue com uma presença de menor visibilidade e, muitas vezes, até desacreditada diante dos seus escândalos. O clero, em crise numérica, cada vez mais ocupará em menor grau as responsabilidades de outrora. Deste modo, a visibilidade da Igreja terá que depender mais do laicato, o que torna a sua apresentação diferenciada, pois a massa leiga dominante não tem um rosto especificamente religioso, cultural e ritual dos clérigos para mostrar à sociedade. A diminuição do poder da Igreja na sociedade retira a evidência explícita da mesma, mas lhe dá oportunidade de fazer revisões importantes. ${ }^{66}$ Por outro lado, é preciso que a mudança não seja apenas uma imposição dos tempos, mas um horizonte intrínseco da própria instituição: é preciso que tenhamos consciência de que a Igreja está em processo de reforma, ou seja, está em contínuo aprendizado e purificação. ${ }^{67}$ Neste sentido, ela não caminha apenas contando com a renovação dos corações, mas das suas estruturas, embora isso nos pareça custoso e lento. A força da tradição, com toda a sua beleza e graça, não pode impedir uma mentalidade de mudança em relação ao poder sagrado.

\footnotetext{
${ }^{65}$ TORRES QUEIRUGA, A., O cristianismo no mundo de hoje, p. 33-39.

${ }^{66}$ MOINGT, J., Croire quand même, p. 147-149.

${ }^{67}$ UR 6; EG 26.
} 


\section{Referências bibliográficas}

ALMEIDA, A. J. Igrejas locais e colegialidade episcopal. São Paulo: Paulus, 2001.

ALMEIDA, A. J. O ministério dos presbíteros-epíscopos na Igreja do Novo Testamento. São Paulo: Paulus, 2001.

ALMEIDA, A. J. Presbíteros Comunitários para Comunidades sem Eucaristia. Instituto Humanitas Unisinos, v.78, abr. 2016. Disponível em: <http:// www.ihu.unisinos.br/78-noticias/554044-presbiteros-comunitarios-paracomunidades-sem-eucaristia-artigo-de-antonio-jose-de-almeida $>$ Acesso em: 11 mai. 2018.

BARROS, P. C. Colegialidade Episcopal no Vaticano II: o concílio convidanos a resgatar um dado fundamental da tradição eclesial. Perspectiva Teológica, v.37, n.102, p. 199-224, mai./ago. 2005.

BOFF, L. E a Igreja se fez povo: Eclesiogênese: A Igreja que nasce da fé do Povo. Petrópolis: Vozes, 1986.

BOFF, L. Igreja, carisma e poder. Petrópolis: Vozes, 1981.

BOROBIO, D. (Org.). A celebração na Igreja. São Paulo: Loyola, 1990. vol. 1.

BRIGHENTI, A. Do sacerdote celebrante a uma assembleia sacerdotal: Em que o Vaticano mudou a Igreja 3. Amerindia, jan. 2018. Disponível em: $<\mathrm{http}$ // www.amerindiaenlared.org/contenido/12094/do-sacerdote-celebrante-a-umaassembleia-sacerdotal-em-que-o-vaticano-ii-mudou-a-igreja-3/>. Acesso em: 11 mai. 2018.

BRIGHENTI, A. Igreja comunidade e Igreja local. In: CNBB. Igreja, Comunidade de Comunidades: experiências e avanços. Brasília: CNBB, 2009.

CASTILlO, J. M. A ética de Cristo. São Paulo: Loyola, 2010.

CASTILLO, J. M.¿Hacía dónde va el clero?: cinco cuestiones candentes. Madrid: Propaganda Popular Católica, 1971.

CASTILlO, J. M. Jesus: a humanização de Deus. Petrópolis: Vozes, 2015.

CASTILlO, J. M. O novo papa, novo modelo de sacerdote. Instituto Humanitas Unisinos, abr. 2013. Disponível em: <http://www.ihu.unisinos. 
br/noticias/519310-o-novo-papa-novo-modelo-de-sacerdote-artigo-de-josemaria-castillo>. Acesso em: 20 jan. 2018.

CASTILlO, J. M. O problema da autoridade na Igreja Católica. Instituto Humanitas Unisinos, jun. 2013. Disponível em: $<$ http://www.ihu.unisinos.br/ noticias/521153-o-problema-da-autoridade-na-igreja-catolica-artigo-de-josemaria-castillo>. Acesso em: 18 jan. 2018.

CASTILLO, J. M. Víctimas del pecado. Madrid: Trotta, 2004.

CELAM. Documento de Aparecida - texto conclusivo da V Conferência Geral do Episcopado Latino-Americano e do Caribe: 13-31 de maio de 2007. Brasília: Edições CNBB; São Paulo: Paulus / Paulinas, 2007.

CNBB. Comunidade de comunidades - uma nova paróquia: a conversão pastoral da paróquia. São Paulo: Paulinas, 2014. (Doc. 100).

CNBB. Cristãos leigos e leigas na Igreja e na sociedade: sal da terra e luz do mundo (Mt 5,13-14). São Paulo: Paulinas, 2017. (Doc. 105).

CNBB. Diretrizes para o diaconato permanente da Igreja no Brasil: formação, vida e ministério. São Paulo: Paulinas, 2012. (Doc. 96).

COMBLIN, J. O povo de Deus. São Paulo: Paulus, 2002.

CODINA, V. A missão como renovação eclesial. In: AMERINDIA. A missão em debate: provocações à luz de aparecida. São Paulo: Paulinas, 2010.

CODINA, V. Eclesiologia do Vaticano II. Perspectiva Teológica, v.45, n.127, p. 461-472, set./dez. 2013.

CODINA, V. Para compreender a Eclesiologia a partir da América Latina. São Paulo: Paulinas, 1993.

CODINA, V. Para onde vai a Igreja?. Instituto Humanitas Unisinos, ago. 2013. Disponível em: <http://www.ihu.unisinos.br/noticias/522787-paraonde-vai-a-igreja-artigo-de-victor-codina $>$. Acesso em: 11 mai. 2018.

CÓDIGO de Direito Canônico. São Paulo: Loyola, 2011.

CONCÍLIO VATICANO II. Constituição Dogmática Lumen Gentium. Petrópolis: Vozes, 1969.

CONCÍLIO VATICANO II. Decreto Unitatis Redintegratio. Petrópolis: Vozes, 1969.

FRANCISCO, PP. Evangelii Gaudium: Exortação Apostólica sobre o anúncio 
do Evangelho no mundo atual. Brasília: Edições CNBB, 2013.

GIDDENS, A. Un mundo desbocado: los efectos de la globalización en nuestras vidas. Madrid: Taurus, 2000.

GONZÁleS FAUS, J. I. Nenhum Bispo Imposto: S. Celestino, Papa. São Paulo: Paulus, 1996.

GRESHAKE, G. Ser sacerdote hoy. Teologia, praxis pastoral y espiritualidade. Salamanca: Sígueme, 2010.

LEUSBAUPIN, I. (Org.). Igreja: comunidade e massa. São Paulo: Paulinas, 1996.

LOBINGER, F. Padres para amanhã: uma proposta para comunidades sem Eucaristia. São Paulo: Paulus, 2007.

LOBINGER, F.; ALMEIDA, A. J. Equipes de ministros ordenados: uma solução para eucaristia nas comunidades. São Paulo: Paulus, 2009.

MOINGT, J. Croire quand même: libre entretien sur le présent et le futur du catoìholicisme. Paris: Flammarion, 2013.

MOLTMAN, J. Teologia de la esperanza. Salamanca: Sigueme, 1972.

NOLAN, A. Jesus antes do Cristianismo. São Paulo: Paulus, 1987.

PAULO VI, PP. Evangelii Nuntiandi: Exortação Apostólica do Sumo Pontífice Paulo VI sobre a evangelização do mundo contemporâneo. São Paulo: Paulinas, 1976.

SESBOÜÉ, B. Não tenham medo! Os ministros na Igreja de hoje. São Paulo: Paulus, 1998.

SCHILLEBEECKX, E. Por uma Igreja mais humana. São Paulo: Paulinas, 1989.

TABORDA, F. A Igreja e seus ministros. Uma teologia do ministério ordenado. São Paulo: Paulus, 2011.

TORRES QUEIRUGA, A. O cristianismo no mundo de hoje. São Paulo: Paulus, 1994.

WEBER, M. Economia e sociedade: fundamentos da sociologia compreensiva. Brasília: Universidade de Brasília, 2004. 
WEBER, M. Três tipos puros de poder legítimo. Lusofia, 2005. Disponível em: <http://www. lusosofia.net/ textos/ weber_3_tipos_poder_morao.pdf $>$. Acesso em: 20 dez. 2017.

\section{Roberto Nentwig}

Doutor em Teologia pela Pontifícia Universidade Católica do Rio de Janeiro Professor na Pontifícia Universidade Católica do Paraná Curitiba / PR - Brasil E-mail: beto.catequese@gmail.com

Recebido em: 27/01/18 Aprovado em: 19/07/18 